\title{
ラットの実験的膀腅腫瘍発生に及ぼす性ホルモンの影響
}

\begin{tabular}{|c|c|c|c|c|c|}
\hline \multirow{5}{*}{$\begin{array}{c}\text { 東京女子医科大学泌尿器科教室 } \\
\text { (主任: 梅津隆子教授) }\end{array}$} & 河 & 野 & & 南 & 雄 ${ }^{* 1}$ \\
\hline & 佐 & 々 & 木 & 則 & 子*2 \\
\hline & 棚 & 橋 & & 豊 & 子*3 \\
\hline & 村 & 岡 & & 祝 & \\
\hline & 東 & & $ち$ & え & \\
\hline
\end{tabular}

\section{THE EFFECT OF SEX HORMONES ON THE INCIDENCE OF EXPERIMENTAL URINARY BLADDER TUMORS IN RATS}

\author{
Namio Kōno*, Noriko Sasaki**, Toyoko Tanahashi***, \\ Noriko Muraoka**** and Chieko Azuma***** \\ Department of Urology, Tokyo Women's Medical College
}

(Director: Prof. Ryuko Umetsu)

Recently, the incidence of bladder cancer has increased and many chemical substances have been suspected as carcinogens.

Clinically, it is well-known that incidence of human urinary bladder cancer (including papilloma) in female is lower than that in male, female to male ratio being only twenty to fourty per cent. It is also recognized that the urothelium is easily influenced by sex hormones.

The authors have studied the effects of testosterone propionate, estradiol and estriol on experimental bladder tumors induced in eight-week-old Wistar-Imamichi strain male rats by oral administration of $0.02 \mathrm{mg} / \mathrm{head} /$ day of $\mathrm{N}$-butyl-N-(4-hydroxybutyl)-nitrosamine as carcinogen for eight weeks (average total doses: $1.12 \mathrm{mg}$ ).

The results were as follows:

1) In the group which was not treated for twelve weeks after completion of the carcinogen administration, six out of twenty-five cases showed bladder-tumors and two of twenty-five showed hyperplasia.

2) In the group which was injected intramuscularly $3 \mathrm{mg} / \mathrm{kg}$ (body weight) of testosterone propionate (Enarmon-oil ${ }^{\circledR}$ ) one time weekly from the beginning of the carcinogen administration through the twentieth week, nine out of twenty-three cases showed bladder tumors and two were with hyperplasia.

3) In the group which was injected intramuscularly $3 \mathrm{mg} / \mathrm{kg}$ (body weight) of estradiol (Ovahormone benzoate ${ }^{\circledR}$ ) one time weekly from the beginning of the carcinogen administration through the twentieth week, two out of twenty-three cases developed bladder tumors and five were with hyperplasia.

*At present, Department of Urology, Tokyo Electric Power Hospital.

**Nishinippori Clinic (5-24-7, Nishinippori Arakawa-ku, Tokyo, Japan).

***Department of Urology, Okayama University School of Medicine.

****Department of Dermatology, National IInd Tokyo Hospital.

*****Department of Dermatology, Tokyo Medical College.

現在 ${ }^{* 1}$ 東京電力病院泌尿器科

*2 西日暮里クリニック

*3 岡山大学医学部泌尿器科教室

*4 国立東京第二病院皮底科

*5 東京医科大学传店科教室 
4) In the group which was injected intramuscularly $3 \mathrm{mg} / \mathrm{kg}$ (body weight) of estriol (Estriel-depot ${ }^{\circledR}$ ) one time weekly from the beginning of the carcinogen administration through the twentieth week, two out of twenty four cases showed bladder tumors and three were with hyperplasia.

5) In the group which was not treated for twenty weeks, none was with bladder tumor or hyperplasia.

There were significant difference between the testosterone propionate group and the estradiol group ( $p<0.02)$, and the testosterone propionate group and the estriol group $(p<0.02)$ in the incidence of bladder tumor.

But there was not a significant difference between the testosterone propionate group and estriol group $(\mathrm{p}=2.704)$ in the incidence of bladder tumor or hyperplasia.

\section{はじめに}

乳腺，肺などを除き，同一臓器における腫瘍の発生は 女性よりも男性に高頻度にみられ, 膀胱腫瘍の発生頻 度も女性は男性 の $20 〜 40 （ ２ 0 ） \%$ を占めるにすぎな $\left(\right.$ (1) $^{-4)}$ (7) (0) 43).

また, 近年, 膀胱腫瘍発生頻度の増加とともに生活環 境に拈ける carcinogen として化学物質が多数指摘され， 膀胼腫瘍に限らず，きわめて強力な carcinogen として 新しく分類に加兄られたものに有機 N-nitroso-compounds がある5) 6) 37743).

ところで, 膀腅腫場がわれわれの生活環境の中で比較 的純粋な形の carcinogens に由来する点でニニークとさ れる ${ }^{35)}$ ことは周知であるが，特殊な化学労働者にみら れる職業性膀胱癌を除いたかかる carcinogens への曝露 は等しいと考えられる自然発生膀胼癌においても男性が 女性よりもその発生頻度が高いという臨床的事実は興味 ある主題である (Table 1).

また，年令の問題とは別に，その質的・量的構成は種 々ではあつても, 性ホルモンの立場よりみれば両性とも

\section{表 1 Female to Male Ratios in Bladder Tumors} (principally, urothelial tumors)

1. T. Ichikawa-1954

Urothelial Tumor 26

(Cases)

2. M.M. Melicow-1955

Papilloma 26

Papillary Carc. 1

33

Papillary Carc. 2.

Papillary Carc. 3. 25

Papillary Carc. $4 . \quad 25$

Nonpapillary Carc. $\quad 28$

Squamous Cell Carc. 32

Adenocarc. (Cystitis glandularis)

14
3. Dorn Cutler-1955

$\begin{array}{lr}\text { White } & 43 \\ \text { Non-white } & 112\end{array}$

4. F.K. Mostofi-1956

$\begin{array}{lrr}\text { Total } & 32 & (2,634) \\ \text { Noninfiltrating } & 27 & (1,086) \\ \text { Papillary I. } & 27 & (332) \\ \text { Papillary II. } & 27 & (754) \\ \text { Infitrating } & 36 & (1,548) \\ \text { Papillary and Infiltrating } & \text { II . }\end{array}$

Papillary and Infiltrating II .

33 ( 668)

Papillary and Infiltrating III.

$32 \quad(343)$

Infiltrating II and III.

5. D.B.J. Ashley-1969

$42 \quad$ ( 537)

Bladder Tumor

6. M.G. Arellano et al.-1972 27

7. R.R. Asalet al.-1974 50

8r R. Oyasu et al.-1974 39 (Approximately 20,800 )

9. M.M. Melicow-1974

Total

Primary

36

(910)

Secondary

10. P.P. Anthony-1974

( 840$)$

12 (138 including

4 renal pelvis tumor 5 and 42 urethra tumors)

に chemical hermaphroditism である ${ }^{910)}$. そして女子 の膀胼三角をふくむ膀脂頝より尿道が胵とともに Sinus urogenitalis に由来し, 成熟婦人においては性周期と之 もにかかる下部尿路上皮が腟上皮と同じ変化をしめす事

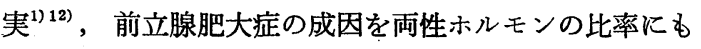
とめれば(3)14)，女性はいうに及ばず，男性に和いても膀 胱頝より尿道前立腺部にこれらに対する receptor の存 在は当然推湘される。また腎腺癌と estrogen の問題も 種々論じられており ${ }^{15)-18)}$, Urothelium は性ホルモンに 
影響されると考えざるをえない。

原発性膀胼腫瘍の90\%前後は urothelial で，良性乳頭 腫も气の再発性・多発性傾向より，臨床的には悪性腫痦 として取りあつかわ机ている。

N-butyl-N-(4-hydroxybutyl)-nitrosamine(BBN と略) を ラットに経口投与すると, 組織学的にも, 組織化学的 にも七ト膀胱移行上皮腫瘍類似の膀胱腫瘍をつくりう

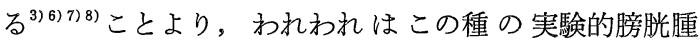
瘍発生頻度の性差"), ならびに testosterone propionate （Test. p. と略）と estriol の影響について報告した ${ }^{3)}$ 。 しかし後者の実験は例数も少なかつたし，これを再確認 する意味もあつて，BBN によるラット膀胱腫瘍発生に 対するTest. p., estriol とともに estradiol の影響をみた ので報告する。

\section{実験準備}

1. 実験動物：

生後 8 週令の Wistar-Imamichi 系雄性ラット（椎憍 商店）125匹を使用し，これを 5 匹ずつに分けて 金網製 ケージに群飼育した。

\section{Carcinogen:}

N-butyl-N-(4-hydroxybutyl)-nitrosamine はイヅミ化学 社製を使用した。

3. 性ホルモン:

1) Testosterone propionate:

エナルモン油液®（1 管10mg，帝国臟器社製）を使用 した。

\section{2) Estradiol:}

安息香酸エストラジオール水性懸濁注射液であるオバ ホルモンベンッアート水性懸濁注射液®（1管 $1 \mathrm{mg}$ ，帝 国臟器社製）を使用した。

3) Estriol:

プロピオン酸エストリオールであるエストリール・デ ポー®（1 管10mg，持田製薬社製）を使用した。

\section{実験方法}

ラットを5 群に分けた。

すなわち，25匹は一切の処置を加光ない対照（nontreated 群）とし，他の 100 匹は BBN を投与するととも

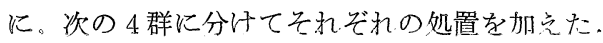

なお BBN は0.02mg/head/day になるように，Tween80 を加えて水道水に分散し, 自由吸水として 8 週間投与 し，穴の後は水道水のみとした。

1. Testosteron propionate 併用群 (Test.p. 群) : BBN 投与開始と同時に，毎週 1 回，エナルモン油液を体重 $\mathrm{kg}$
あたり $3 \mathrm{mg}$ 筜筋に注射し，実験終了迄の 20 週間，合計 20 回投与した。

2. Estradiol 併用群 (Estradiol 群) : BBN 投与開始 と同時に，オバホルモン。ベンッアートを毎週 1 回，体 重 $k g$ たり $3 \mathrm{mg}$ 警筋に注射し, 実験終了迄の 20 週間, 20回投与した.

3. Estriol 併用群（Estriol 群）：BBN 投与開始之同 時に, エストリール・デポーを毎週 1 回, 体重kgあたり $3 \mathrm{mg}$ 管筋飞注射し，実験終了迄の 20 週間，20回投与し た。

4. BBN のみの投与群 (BBN 群)：上記の方法に上 り，BBN のみを投与し，その他には何等の処置も加兄 なかつた。

以上の実験で，飼料は CE-2（日本クレア社製）を使 用し， $24 \pm 1{ }^{\circ} \mathrm{C}$, 湿度 $55 \pm 5 \%$ の恒温恒湿環境下飞飼育 した。

また，全例，実験開始 20 週経過後にエーテル麻酔下に 屠殺し，10\%ホルマリン溶液を膀脱内に充満して固定後 に全摘した．そして直ちに，肉眼的検索を加えた後，10 \%ホルマリン溶液中に浸して固定，ヘマトキシリン・エ オジン染色を施して組織学的検索を加えた。

\section{突験経過ならびに成績}

Test. p. 群の中，第 4 ，第 9 週目に 1 匹ずつ, Estradiol 群の中, 第 4 , 第15週目に 1 匹ずつ, Estriol 群の 1 匹 が第 9 週目に死亡した. Test. p. 群の第 9 週目に死亡し たものは共喰いで，これを除いた 5 匹は剖検上，肺炎に よるもので，膀胱に腫瘍の形成はなかつた。

各群の実験経過中に打沙る体重の変動をしめすと図 1 の如くで, 12，13週目に BBN 群と Test.p. 群に一過 性の体重減少がみられたが，Non-treated 群，BBN 群，

図 1 Chanes of Body Weight

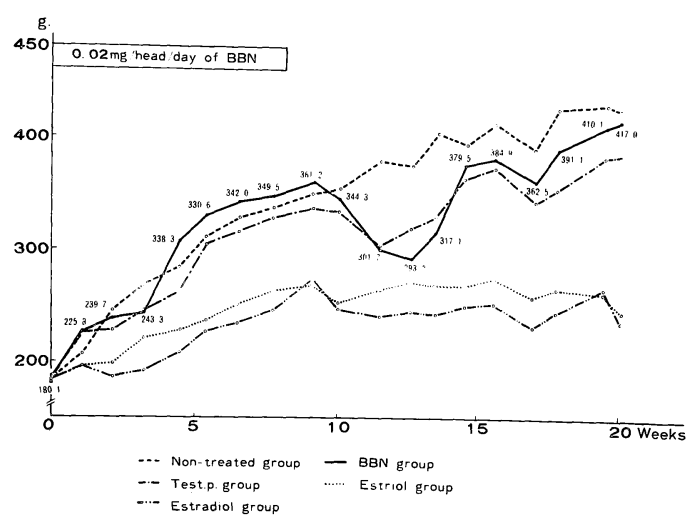


図 2

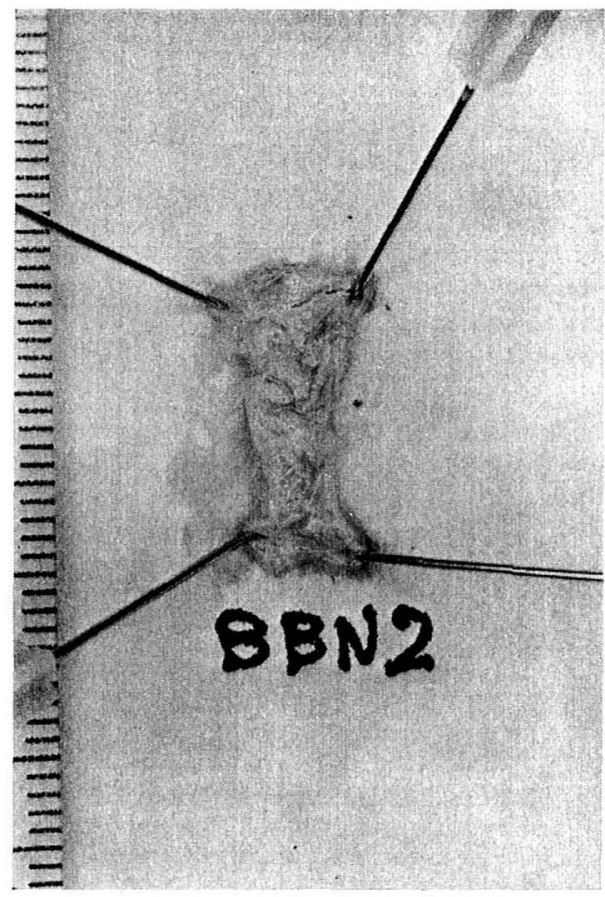

Test. p. 群と Estradiol 群, Estriol 群がほぼ同一の体重 曲線をしめした。そして実験終了時には, 前 3 者は後 2 渚の約 2 倍近くの体重であつた。

今回の実験によつて惹起された膀胱腫㕫の肉眼的所見 は図 2,3の如くで，組織学的所見は，写真 4, 5, $6 ， 7$ の加くであつた。

各実験群の病理組織学的所見をまとめると表 2 の如く になる。

BBN 群では，25匹中腫陽形成 6 匹 (G- II : 1 匹， GII : 5 匹) (24\%), 過形成 2 匹 $(8 \%)$ で, Test. p. 群 では23匹中，腫瘍形成 9 匹（G-II：2 匹，G- I ： 7 匹）

$(39.1 \%)$, 過形成 2 匹 $(8.7 \%)$, Estradiol 群では23匹 中, 腫瘍形成 2 匹 (G- II ： 1 匹, G- I : 1 匹) (8.7\%), 過形成 5 匹 (21.7\%), Estriol 群では24匹中，腫瘍形成 2 匹 (何れも G-I ) (8.3\%), 過形成 3 匹 (12.5\%) であ つた。

\section{考按}

発癌機構は複雑である。

人種により多少異なるが, 一般に生殖器, 乳腺, 肺, 甲状腺, 結腸などを除く臓器癌の発生頻度は, 藏器によ つて多少異なるが, 女性は男性よりも少なく，まして女
図 3

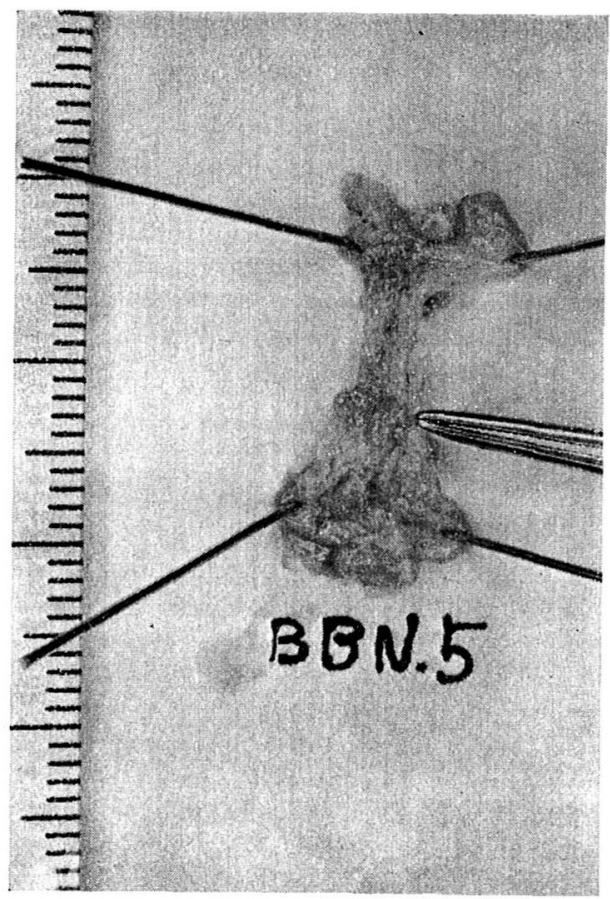

性の膀胱腫瘍は男性の約20～40（～50）\%にみられるに すぎない.

先にものベた如く, 原発性膀胱腫瘍の約 $90 \%$ は urothelial で, しかも良性乳頭腫もとの再発性・多発性の問題 より臨床的には悪性媑瘍としてとりあつかわれている。 また膀胱腫瘍は治癒せしめえても, 上部尿路尰陽の併 発, 腫瘍膀胱の婳瘍部以外や尿管の前癌性変化, 実験的 膀脱腫瘍が尿流遮断部には発生しない郝告などより， 尿中 chemical carcinogen の存在が指摘される7)37). Bryan \& Yoshida $(1971)^{22)}$ は，ヒトならびに動物実験 による膀胱癌は化学物質が主として原因をなすとし, virus p physical agents 由来のものはごく僅かであると いう.

末開発地带よりも開発工業地帯が，また田舎よりも都 市部が膀脂癌の発生頻度や死亡率が高い報告 ${ }^{37}{ }^{40)}$ もあつ て，生活環境の中に明らかな原因々子として特殊な化学 物質が指摘される 27) 37).

1859年, Rehn の報告にはじまる職業性膀胱癌は周知 であるが，この職業性のものは全膀脂癌の約 $1 \%$ 占め るにすぎないとされる、そしてこれに関連した職業や地 域住民の発癌頻度も総じて $1 \%$ は高いとされる ${ }^{37)}$. 
図 4 Showing slight epithelial hyperplasia. The epithelial cells are 4 to 6 layers in thickness and the subepithelial zone widens. $(\times 100$, H. \& E.)

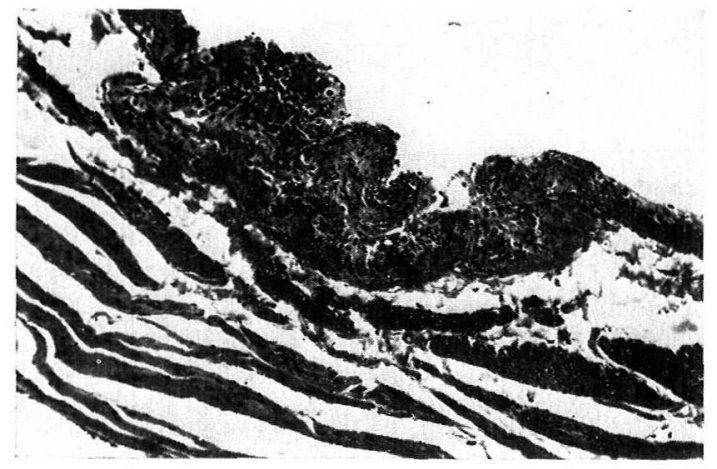

橉 6 Showing early benign transitional cell tumors (G- I or Stage I ). Note the patch of squamous metaplasia in the tumor. $(\times 100, \mathrm{H}$. \& E.)

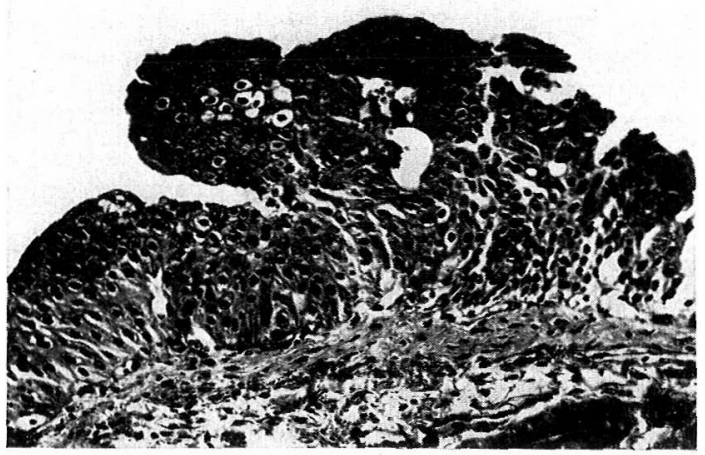

Schistosomiasis によるもの队，膀胱結石，膀胱外反 症, 秝室, 尿道狭窄を原因とするもの 職業性の自然発生膀胱癌の外因的成因として, 芳否族了 ミンを含も食䬣や化粧品，antioxidants るくさゴム製 品, 漂白洗剂や䄷き粉, 人工廿味料, 色素分解飞より産 生される芳香族アミン，織物工場から活水中に排出され たアゾ色素の E. coli の如き細菌によつて分解された benzidine をくくむ芳香族〉ミン，食领の nitrosamine • bracken fern・バナナ, 薬剤としての N-[4-(5-nitro-2furyl)-2-thiazolyl]acetamide, 契堙などが指摘される ${ }^{37)}$.

もちろん tryptophan 代謝異常や $\beta$-glucuronidase ( $\beta$ G. と略）の役割も度外視でさない。しかし，Wisconsin の膀胱癌患者の tryptophan 代謝異常を検討乙，男性の
図 5 High magnification of photo. 3. Showing columnar cell metaplasia in a region of the slight hyperplasia (arrow) and inflammatory infiltration in the subepithelial tissue. $(\times 100$, H. \& E.)

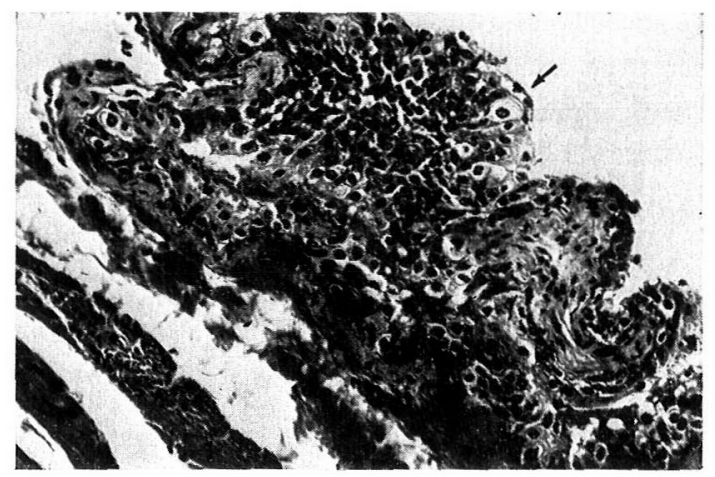

図 7 Showing solid ingrowths of the transitional cell tumors (G- I G- II $)(\times 100$, H. \& E.)

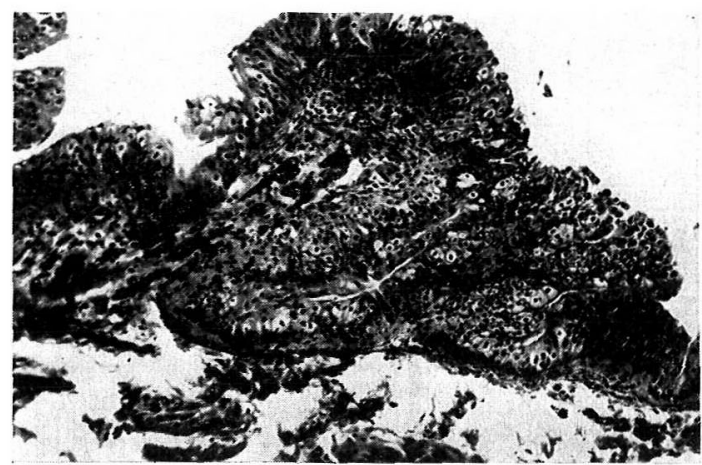

それは35\%であつたのに対して女性は75\%であつた ${ }^{38)}$ いら報告もある。

したがつて, 非職業性自然発生膀胱癌が，上述の外因 性 chemical carcinogens に起因するとした場合，国に より人種によつて多少の相違があつた ${ }^{40)}$ とても，その 発生率が女性よりも男性に有意に高い事実は無視できな い。さてや米国やカナダでは，男性の膀胱癌は増加し ているのに女性は減少しているとの報告亦である ${ }^{40) 43)}$.

われわれはかかる事実をるまえて，BBNによるラット 膀胱腫瘍の性による発生頻度の差を生後 6 週令の Wistar-Imamichi 系ラットに6 週間 carcinogen 孛経口投与 し，关の後38週間生存されたものについてみた。纮倠の生 存 5 匹中，乳頭腫が 2 匹，過形成が 2 匹久られたのに対 
して雌の生存14匹中, 乳頭腫や過形成をみたものは全く ない。両群間の腫瘍発生率は10\%の危険率で，また過形 成をふくめた発生率は $0.1 \%$ の危険率で有意差があるこ とを認め，BBNによるラットの膀胱腫瘍は雌よりも雄に 発生しやすいことを報告した ${ }^{7)}$.

また，性ホルモンとしての testosterone propionate と estriol の BBN の雄性ラット膀胱腫瘍発生に及ぼす影響 をみて, testosterone propionate 投与群は 9 匹中腫瘍形 成が 5 匹，過形成が 1 匹であつたのに対し，estriol 投与 群では 9 匹中，腫瘍を形成したものはなく，過形成が? 匹にみられたにすぎず，膀胱腫瘍の発生率は両群間に推 計学的にも有意差があつた。しかし例数が少なく結論め いたことはひき出せなかつたので，今回，例数を増や してこれの再確認と同時に estradiol の影響をも検討し た.

実験結果は Table 2 にしめすごとくであった。

表 2 Pathologic Changes of the Urinary Bladder

\begin{tabular}{|c|c|c|c|c|c|}
\hline \multicolumn{2}{|c|}{ Path. } & B B N & Test. p. & Estradiol & Estriol \\
\hline \multirow{2}{*}{ Tumor } & $\mathrm{G}-\mathrm{II}$ & $\left(\begin{array}{c}1 \\
4 \%\end{array}\right)$ & $\begin{array}{c}2 \\
(8.7 \%) \\
\end{array}$ & $(4.3 \%)$ & \\
\hline & $G-I$ & $\begin{array}{c}5 \\
(20 \%) \\
\end{array}$ & $\begin{array}{c}7 \\
(30.4 \%) \\
\end{array}$ & $\begin{array}{c}1 \\
(4.3 \%)\end{array}$ & $\begin{array}{c}2 \\
(8.3 \%) \\
\end{array}$ \\
\hline \multicolumn{2}{|c|}{ Hyperplasia } & $\left(\begin{array}{c}2 \\
(8 \%)\end{array}\right.$ & $(8.7 \%)$ & $\frac{5}{(21.7 \%)}$ & $\frac{3}{(12.5 \%)}$ \\
\hline \multicolumn{2}{|c|}{ Non Partiocular } & $\begin{array}{c}17 \\
(68 \%)\end{array}$ & $\begin{array}{c}12 \\
(52.2 \%) \\
\end{array}$ & $\frac{16}{(69.6 \%)}$ & $\begin{array}{c}19 \\
(79.2 \%)\end{array}$ \\
\hline \multicolumn{2}{|c|}{ Total } & $\begin{array}{c}25 \\
(100 \%)\end{array}$ & $\begin{array}{c}23 \\
(100 \%)\end{array}$ & $\left(\begin{array}{c}23 \\
(100 \%)\end{array}\right.$ & $\begin{array}{c}24 \\
(100 \%)\end{array}$ \\
\hline
\end{tabular}

ただ両ホルモンの 投与形式が異なり，先回の実験で は, testosterone propionate として Enarmon 水性懸濁 液®の $1 \mathrm{mg} / \mathrm{kg}$ （体重）を週 3 回皮下注射によつて，ま た estriol は Estriel 水性懸濁液®の $1 \mathrm{r} / \mathrm{kg}$ (体重)を週 3 回皮下注射によつて，それぞれ20週間投与した。

今回の実験では, Test. p. 群の生存23匹中, 膀胱腫瘍 は 9 匹 (39.1\%，G- II : 2 匹，G- I : 7 匹),過形成は 2 匹 (8.7\%) とみられたのに対して, Estriol 群の生存 24 匹中, 膀脱腫瘍は 2 匹 $(8.3 \%$, 何れも G- I ), 過形成は 3 匹 $(12.5 \%)$ で, 両群間の腫瘍発生率は, Fisher の直 接確率計算法で $\mathrm{P}=0.0145$ となり, 明らかに有意羑をみ た。

ところで, BBN のみを投与した BBN 群では, 生存 25匹中，膀胱腫場は 6 匹（24\%，G- II : 1 匹，G= I : 5 匹), 過形成は 2 匹 $(8 \%)$ にみられ, Test. p. 群よりも 腫瘍発生率は低かつたが，推計学的に両群間に有意差は
なかつた。また，BBN 群の腫瘍発生率は Estriol 群より も高かつたが, 推計学的に両群間に有意差はなかつた。 すなわちBBNによる雄性ラットの膀脱腫瘍の発生に, testosterone propionate は促進的に作用し, estriol は抑 制的であり, Test .p. 群と Estriol 群との腫瘍発生頻度 には明らかに有意差がある。

また Estradiol 群では, 生存23匹中, 膀脱腫瘍は 2 匹 (8.7\%，G- II ：1 1 匹，G- I : 1 匹), 過形成 5 匹（21.7 \%)で，BBN 群よりも腫瘍発生率は低かつた。すなわ ち, Estradiol もこの種の実験腫瘍の発生に抑制的に作 用するが, Estradiol 群と BBN 群との間には推計学的に 有意差はなかつた。しかし Test. p. 群と Estradiol 群と の間の腫瘍発生率の比較では $\mathrm{P}=0.0175$ で有意差があつ た。

Estriol の方が Estradiol よりも僅か飞抑制的である が，両群間の腫瘍発生率には有意差はなかつた。

Ito ら $(1969)^{199}$ は BBN によるラットの実験的膀胱腫 瘍発生の光顕, 電顕, autoradiography の所見より, 可逆 性の precursor lesion 之非可逆性の hyperplasia に分けて 拈り, Tiltman ら (1971) ${ }^{20)}$ は N-(4-(5-nitro-2-furyl)-2thiazolyl) formamide によるラットの実験的膀胱腫瘍に 抒いて, carcinogen 投与中止により，その核変化は10週 後まで存続しても hyperplasia は 4 週後には退縮する事 実より，下部組織にまで侵襲したものをはじめて癌とし てとりあつかつている. 何れにせよ, 過形成をふくめて の膀脱腫瘍発生率は, BBN 群32\%, Test. p. 群 $47.8 \%$, Estradiol 群31.8\%, Estriol 群20.8\%であつたが, 各群 間で有意差のあるものはなかつた。

Bonser ら (1964) ${ }^{23)}$ は 4-ethylsulphonyl-naphthalene-1sulphonamide の carcinogenic action はラットやマウス で雌性の方が雄性よりもその感受性は 3 倍も高かつたと いら.

河野 $(1971)^{6)}$ は今回と同じモデル実験で，20週間BBN を投与し，その後16週間生存しえた雌・雄それぞれ4匹 全例飞腫瘍の発生をみ，また樋口ら (1972) ${ }^{24)} も B B N を$ 20 週以上投与乙て両性間の腫瘍発生頻度に差を認めなか つたという。また岡島ら $\left(1969^{41)} ， 1970^{42)}\right)$ はBNを 21〜24调間投与封の除鼻術や diethylstilboestrol (D.E.S. と略）の投与はラットの膀胱腫瘍の発生に影響しなかつ たが，BBN 8 週間投与では D.E.S. の皮下挿入によつて 腫瘍の增殖が抑制されたという。

Oncogenesis の早期についてはほとんど理解されてい ない。細胞レベルでの carcinogenesis が，中原，Druc- 
krey のしめす如く，多くの不可逆的段階の累積があり， これらすべての段階を経て明らかな neoplasm として発 展するものとすれば, 当然, この間に括ける変化は普遍 的に行なわれているとの推測は難くない，そこで，一旦 完成された neoplastic cell も生体の防御機構によつて 破壊されることは長い間推測されてきたし 25 , 事実, 文 献上 176例 (この中 31 例は hypernephroma) の癌の自然 退化の報告 ${ }^{26)}$ もある。

性による腫瘍発生頻度の相違についての考察は，既に われわれは度々言及したしい7，ここでは簡単に論及す るにとどめる。

Ashley ${ }^{112)}$ は，性による腫湯発生頻度の相違を，

（1）洇煙やcarcinogensをふくむ労働環境への曝露な ぞ，男女の生活習慣や環境の相違

（2）性ホルモン構成の相違

（3）体格の相違

（4） X chromosome 構成の相違一一性は 2 個の $\mathrm{X}$ chromosome をるち, 少なくともその 1 個は immunogl obulin 産生に関与する genesを carry し，これがために 女性の方が男性よりも免疫能が強い280

などによるとした，そして上記（1)，(2) の条件が ほとんど無視できる 5 歳以下の小児に括いても，男児の 方が女児よりも腫瘍の発生率が高い事実は, これらの項 目では説明が不可能であることより, 乳癌が 2 個のX chromosome を有する場合に発生しやすく, Klinefelter 症候群飞乳癌が多いといら指摘もある ${ }^{44)}$ が，(4)のX chromosome の免疫学的意義深納するのが現在の大勢 である.すなわち incipient neoplasm の “foreign” cell に対して，女性は男性よりるこれを not-self として認知 しやすいし，graft rejection と同一型式で，これを破壊 する可能性も高く，女性の腫場発生頻度を低下させる ことにもなるし，事実，潜在性癌をらくめた臨床的に 明らかな癌腫が発育増大するにつれて，この異常細胞を reject する力が消失することは組織学的にも明らかにさ れている゙

Melicow (1974) ${ }^{4)}$ は膀脱腫瘍が女性よりも男性に多い のは，男性の方が carcinogen をふくさ労働環境に曝露 されやすいことによるとしている。

しかし先の予備的実験 ${ }^{3)}$ や今回の実験成績よりすれ ば, 性ホルモンそのものの発癌促進もしくは抑制作用は 否定すべくもない．

マウスの乳癌発生には, 乳癌 virus, 遺伝条件, ホル モン一とくに estrogen と乳腺刺激ホルモン一の 3
因子が複雑に関与しておゔ，乳癌潜伏期の hyperplastic alveolar nodule はホルモン環境が適当でなければ退縮 するし，乳腺刺激ホルモンが多い状態では異常な速さで 増殖する。すなわち virus が細胞の癌化に関与する因子 (initiating factor, initiator, Berenblum) であり,ホル モンは癌化した細胞の增殖に関与し，条件が整えば癌腫 形成を促進する因子 (promoting factor, promotor) であ るといら ${ }^{29)}$.

すなわち, carcinogen の carcinogenic action と host の関係に括いて成立するものであり, Leistenschneider ら $(1973)^{21)}$ のフェナセチン濫用による腎孟癌はフェナセン 耽溺者の多い女性の方が男性よりもその発生頻度が高か つたとするが如きである。そこでBBNによるラット膀胀 発癌の性差にしても, primary key としての carcinogen の投与量, 投与型式によつて吟味すべきである.

Melicow (1974) $)^{4}$ は膀脱の urothelial tumor 771例中 papilloma が25例で, その中の $60 \%$ ぞ男性であつたのに 対して, carcinoma in situ をふくめた癌性変化746例中 $74.6 \%$ が男性であつたといい, Mostofi (1956) ${ }^{30)}$ の浸 潤型膀胱癌の生存率が男性よりも女性に高いとする報告 にも注目されねばなら奴，そしてこれが免疫能，ひいて は生体防御力が男性よりも女性が強いとする理論よりも 組み立てられる。

本実験結果に対する考察は，先の報告 ${ }^{8)}$ を出づるもの ではない。

1847年, Fishman \& Anylan ${ }^{31)}$ は癌組織では他の健常 部よりも $\beta$-G.の活性值は高いことをしめした. その後， 現在末だ確立されてはいないが， $\beta$-G. の膀腪発癌飞拉 ける役割が Boyland や多くの追試によつて検討されて いることは周知である ${ }^{8)}$ また，その後の Fishman一派 の androgens による腎組織や尿中 $\beta-G$ 活性増強の一連の 研究は，今回の実験に打ける testosterone propionate の promoting 的作用を説明可能にする.

一方, 生体の防御機構は主として細網内皮系(R.E.S.) の機能にあり，内分泌系が R.E.S. 機能の homeostasis に関与し，自然の 3 女性ホルモン—estrogen，estriol， $17 \beta$-estradiol が生体防御機構に招ける principal natural stimulant で, testosterone には R.E.S. と対する効果は

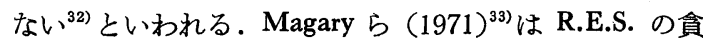
食能が自然抵抗性を反映するといい，臨床的に癌患者に estrogenic compounds を投与して R.E.S. の貪食能を検 討している.

癌に打ける凝固・線溶の意義は, 著者らも検討してい 
るし，種々論議(67) 834) 35)36)されている. 性ホルモンの凝 固・線溶に及ぼす影響の報告も多々ある ${ }^{3)}$. しかしこの 問題は本実験の主題との関係は前 2 者程ではないと考兄 られる。

本実験は雄性ラットを用いた実験であり，かかる興味 ある成績がえられた事実は，X choromosome，ひいては 免疫能の問題ではなく，むしろ testosterone propionate の腎や尿の $\beta-G$, 活性増強や estradial, estriol の R.E.S. 機能賦活よりの解釈の方が無難のようである.

ホルモンは神経系とともに, 各種の臟器組織に作用 し, 内部環境の恒常性維持に重要な軸を構成する.

性によるホルモン構成の相違, 加令とホルモン構成の 変化も重要で, 生殖器や内分泌臓器以外の発癌とその後 の進展についての性ホルモンの影響は無視できないるの であると考えられる。

$$
\text { むすび }
$$

生後 8 週令の.Wistar-Imamichi 系雄性ラットに 0.02 $\mathrm{mg} / \mathrm{head} /$ day の BBN を 8 週間経口投与し，その後12週 間放置したときの実験的膀胱腫瘍発生に及ぼす性ホルモ ンの影響をみた。

1. BBN 群 : 上記要領により，BBN のみを投与した 群で, 25匹全例生存し, この中, 膀脂腫瘍形成は 6 匹 (24\%，G-II：1匹，G-I：5 匹), 過形成 2 匹（8\%） がみられた。

2. Test.p. 群：BBN 投与と同時に， $3 \mathrm{mg} / \mathrm{kg}$ （体重） の testosterone propionate を週 1 回, 20週間筋注により 投与した。生存 23 匹中, 膀脂腫瘍形成 9 匹 $(39.1 \%$, GII：2 匹，G-I：7匹),過形成 2 匹 (8.7\%):がみられ た。

3. Estradiol 群: BBN 投与と同時に, $3 \mathrm{mg} / \mathrm{kg}$ （体 重）の estradiol を週 1 回，20週間筋注により投与した。 生存 23 匹，膀脱腫湟形成 2 匹 $(8.7 \%, \mathrm{G}-\mathbb{I}: 1$ 匹， G- I ： 1 匹),過形成 5 匹（21.7\%）がみられた.

4. Estriol 群 : BBN 投与と同時に, $3 \mathrm{mg} / \mathrm{kg}$ (体重) の estriol を週 1 回，20週間筋注により投与した. 生存 24 匹，膀胱腫瘍形成は 2 匹 $(8.3 \%$,何れも G- I ), 過 形成は 3 匹 $(12.5 \%)$ 飞みられた。

5. 無処置の対照25匹には，膀脱腫瘍形成も過形成も みられなかつた。

な抏, Test. p. 群と Estriol 群間, ならびに Test. p. 群と Estradiol 群間の腫惶発生率には推計学的にも有意 差があつた。

(本論文の要旨は第63回日本泌尿器科学会総会にてロ
演した。な拈本実験は著者らが東京女子医科大学に在籍 中に実施したもので，改めて梅津隆子教授に深謝する。

病理組織学的所見は慶大病理学教室大谷武彦博士に2 て頂いたものであり，記して深謝の意を表する。）

\section{文献}

1) Ashley, D.J.B.: Brit. J. Cancer, 23, 21, 1969.

2) Ashley, D.J.B.: Brit. J. Cancer, 23, 26, 1969.

3) 河野南雄, 佐々木則子：東女医大誌， 43，22, 1973.

4) Melicow, M.M.: J. Urol., 112, 467, 1974.

5）河野南雄：東女医大誌，40, 505, 1970.

6) 河野南雄：東女医大誌，41，111，1971.

7）河野南雄，佐々木則子：東女医大誌，43，767, 1973.

8）河野南雄, 佐々木則子 : 東女医大誌， 43,466 , 1973.

9) Longcope, C., Kato, T. and Horton, R.: J. Clin. Invest., 48, 2191, 1969.

10) Somma, M., Sandor, T. and Lanthier, A.: J. Clin. Endocr., 29, 457, 1969.

11) O'Morchoe, P.J. and O'Morchoe, C.C.C.: Amer. J. Obst. Gynec., 99, 479, 1967.

12）梅津隆子：東女医大誌，39, $1,1969$.

13) Kaufmann, J.: Zschr. Urol., 61, 171, 1968.

14) Wojewski, A., Krasón, S., Roessler, R. and Laska, A.: J. Urol., 92, 568, 1964.

15) Roe, F.J.C. and Mitchley, B.C.V.: Cancer, 20, 2118, 1967.

16) Kirkman, H. and Bacon, R.L.: Cancer Res., 10, 122, 1950.

17) Hajdu, S.I., Berg, J.W. and Footer, F.W.: J. Amer. Geriat. Soc., 18, 433, 1970.

18) Wagle, D.G. and Murphy, G.P.: Cancer, 27, 318, 1971.

19) Ito, N., Hiasa, Y., Tamai, A., Okajima, E. and Kitamura, H.: Gann., 60, 401, 1969.

20) Tiltman, A.J. and Friedell, G.H.: Invest. Urol., 9, 218, 1971.

21) Leistenschneider, W. and Ehmann, R.: Schweiz. Med. Wochenschr., 103, 434, 1973.

22) Bryan, G.T. and Yoshida, O.: Environ Health, 23, 6, 1971.

23) Bonser, G.M. and Clayson, D.B.: Brit. J. Urol., 36, 26, 1964.

24）唃口正士, 上村計夫, 江藤耕作, 重松 俊: 第 60回日泌尿総会, 1972.

25) Reiner, J. and Southam, C.M.: Nature, 5034, 429, 1966.

26) Talley, R.W., Moorhead, E.L., Tucker, W.G., San Diego, E.L. and Brennan, M.J.: J.A.M.A., 207, 322, 1969.

27) Anthony, P.P.: Br. J. Urol., 46, 201, 1974. 
28) Nairn, R.C., Richmond, H.G., McEntegart, M.G. and Fothergill, J.E.: Brit. Med. J., 2, 1335, 1960.

29) 西塚泰章（菅野晴夫, 小林博編）腫瘍病理学, 朝 倉書店, 東京, 1970, 233頁.

30) Mostofi, F.K.: J. Urol., 75, 480, 1956.

31) Fishman, W.H. and Anlyan, A.J.: J. Biol. Chem., 169, 449, 1947.

32) Nicol, T., Vernon-Roberts, B. and Quantock, D.C.: J. Endocrin., 33, 365, 1965.

33) Magary, C.J. and Baum, M.: Brit. Med. J., 15, 3671971

34) 河野南雄, 佐々木則子, 高橋通子, 梅津隆子: 第11回プラスミン研究会報告集，166，1971.

35) 河野南雄, 佐々木則子: 第12回プラスミン研究 会報告集， $67^{\circ} 1972$.

36) 佐々木則子：日泌尿会誌，64，383，1973.
37) Oyasu, R. and Hopp, M.L.: Surg. Gyn. \& Obst., 138, 97, 1974.

39) Brown, R.R., Price, J.M., Friedell, G.H. and Burney, S.W.: J. Natl. Cancer Inst., 43, 295, 1969.

40) Asal, N.R. and Ferguson, S.W.: Oklahoma State Med. Ass., 65, 409, 1972.

41）岡島英五郎, 井本 卓, 平松 㑆, 本宮善恢, 石 川昌義, 伊東信行 : 第57回日泌尿総会, 1969.

42) 平松 㑆, 本宮善恢, 入矢一己, 岡島英五郎, 石川昌義, 日浅善雄: 第58回日泌尿総会, 1970.

43) Arellano, M.G., Linden, G. and Dunn, J.E.: Br. J. Cancer, 26, 473, 1972.

44) Lynch, H.T., Kaplan, A.R. and Lynch, J.F.: J.A.M.A., 229, 809, 1974.

（1975年 3 月 1 日受付） 